\title{
ANTIBACTERIAL EFFECT OF WHITE POMEGRANATE PEEL EXTRACT (PUNICA GRANATUM L) AGAINST STREPTOCOCCUS SANGUINIS
}

\author{
Muthiah Diniasti*, Anita Rosa Delima*, Muhamad Zakki*
}

* Departemen Konservasi Gigi, Fakultas Kedokteran Gigi Universitas YARSI

Correspondence : Anita Rosa Delima, Departemen Konservasi Gigi, Fakultas Kedokteran Gigi Universitas YARSI

Email : anita.rosa@yarsi.co.id, muhamad.zakki@yarsi.ac.id

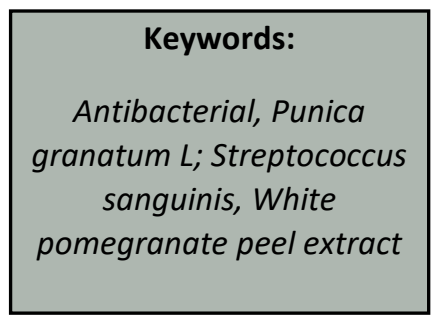

\begin{abstract}
Background: Streptococcus sanguinis is one of the bacteria that plays role in the occurrence of caries, acts as an anchor for the attachment of other oral microorganisms that will form dental plaque in the development of caries. The extract of White Pomegranate peel has several compounds such as flavonoids and tannins that have potential as an antibacterial. Objective: To analyze the antibacterial potency of white pomegranate peel extract against Streptococcus sanguinis bacteria.
\end{abstract}

Methods: Using disc diffusion method (Kirby-Bauer) with 7 treatment groups $(n=4)$. Streptococcus sanguinis bacteria is inoculated in agar medium on petri dish, dripped $50 \mu \mathrm{l}$ to each disc with $100 \%, 50 \%, 25 \%, 12,5 \%, 6,25 \%$ concentration of pomegranate skin extract, and control group. The petri dish is placed in the incubator at $370 \mathrm{C}$ for 24 hours. Each of antibacterial is observed with the presence of inhibition zones around the disc. The analysis uses Kruskal-Wallis and followed by the Mann-Whitney test.

Results: There are inhibitory zones for all treatment concentrations, except for concentration of $12.5 \%$, and $6.25 \%$. There is a significant difference in the concentration of pomegranate skin extract towards the growth of Streptococcus sanguinis bacteria.

Conclusion: White pomegranate skin extract has antibacterial potency at $25 \%$, $50 \%$, and $100 \%$ concentration

\section{PENDAHULUAN}

Streptococcus sanguinis merupakan bakteri gram positif yang berperan dalam kolonisasi bakteri dalam rongga mulut. Streptococcus sanguinis juga berperan sebagai penjangkar untuk perlekatan mikroorganisme oral lain yang akan berkolonisasi di permukaan gigi, kemudian membentuk plak gigi dan berkontribusi terhadap perkembangan karies. ${ }^{1,2}$

Berkumur dengan chlorhexidine adalah salah satu cara yang dapat dilakukan untuk kontrol plak. Chlorhexidine bekerja dengan mengubah integritas membran sel bakteri. ${ }^{1}$ Penggunaan chlorhexidine secara terus menerus dalam jangka panjang dinilai memiliki efek samping, diantaranya menyebabkan rasa terbakar pada mukosa mulut, mengganggu indera perasa, pewarnaan pada gigi, erosi mukosa mulut dan xerostomia, ${ }^{3}$ sehingga diperlukan langkah untuk beralih menggunakan bahan alternatif lain yang lebih aman dan alami, seperti obat tradisional.

Buah delima (Punica granatum L) cukup popular digunakan sebagai bahan obat tradisional di dunia herbal. ${ }^{4} \mathrm{Di}$ indonesia, terdapat tiga jenis buah delima yang tersebar dan dikelompokkan berdasarkan warna buahnya, yaitu delima putih, delima merah, dan delima hitam. Buah delima telah banyak diakui bermanfaat salah satunya untuk 
mengobati gangguan pencernaan, seperti diare dan disentri. Semua bagian tanaman delima dapat dimanfaatkan untuk pengobatan, ${ }^{5}$ dan semua bagian tanaman ini bersifat antivirus dan antibakteri. Beberapa senyawa fitokimia dilaporkan dapat menghambat pertumbuhan bakteri penyebab penyakit. ${ }^{6}$ Delima putih sering digunakan sebagai obat tradisonal, dikarenakan kandungan flavonoid dan taninnya yang tinggi. ${ }^{4}$

Kulit dari buah delima juga dikatakan memiliki antibakteri tertinggi. ${ }^{4}$ Kulit buah delima dapat juga digunakan sebagai bahan antibakteri terhadap infeksi rongga mulut khususnya karies gigi. Kulit buah delima mengandung fenolik yang terdiri dari flavonoid dan tanin yang berperan sebagai antibakteri. Kulit buah delima tidak menutup kemungkinan memiliki daya antibakteri terhadap Streptococcus sanguinis. ${ }^{7,8}$

Penelitian Sadeghian tahun 2011, menyatakan bahwa ekstrak kulit buah delima memiliki efek antibakteri yang tinggi terhadap fungi, bakteri gram positif dan gram negatif. ${ }^{9}$ Penelitian Cut $R$ tahun 2013 juga menyatakan bahwa ekstrak kulit buah delima mampu secara efektif menghambat pertumbuhan Streptococcus mutans dengan konsentrasi sebesar $30 \% .^{10}$

Berdasarkan uraian di atas kulit buah delima putih mempunyai potensi daya antibakteri, namun penelitian terhadap Streptococcus sanguinis masih terbatas sehingga peneliti terdorong untuk melakukan uji daya antibakteri ekstrak kulit buah delima putih terhadap bakteri Streptococcus sanguinis secara in vitro.

\section{METODE PENELITIAN}

Penelitian ini telah mendapatkan sertifikat kelaikan etik No: 369/KEP-UY/BIA/XII/2017. Penelitian ini merupakan penelitian eksperimental laboratorik. Penelitian dilaksanakan pada bulan November - Desember 2017 di Laboratorium
Herbal dan Mikrobiologi Universitas Yarsi. Uji Zona hambat bakteri yang digunakan adalah metoda disc diffusion (Kirby Bauer) untuk menentukan aktivitas agen bakteri. Protokol penelitian ini sudah disetujui oleh Komisi Etik Penelitian Universitas YARSI.

Penelitian ini menggunakan media Agar Darah Plate (ADP), etanol $70 \%$, chlorhexidine 0,2\%, Brain Heart Infusion Broth (BHI-B), blank disc, sediaan bakteri Streptococcus sanguinis, kertas saring, rotary evaporator, petri dish, kapas lidi steril, mikropipet, jarum oese, vortex, inkubator, aquadest steril dan penggaris.

Penelitian ini menggunakan kulit buah delima putih (Punica granatum L). Kulit buah delima putih yang sudah dikeringkan diambil 350 gram dan dimaserasi dengan pelarut etanol $70 \%$ selama 1x24 jam. Hasil maserasi disaring dengan kertas saring dan dipekatkan dengan menggunakan alat rotary evaporator pada suhu tidak lebih dari $60^{\circ} \mathrm{C}$. Ekstrak kental yang dihasilkan dibiarkan pada suhu ruangan hingga seluruh pelarut etanol menguap.

Metoda yang digunakan adalah disc diffusion (Kirby Bauer) untuk menentukan aktivitas agen bakteri. Disc yang berisi ekstrak kulit buah delima putih diletakkan pada media agar yang telah ditumbuhi bakteri Streptococcus sanguinis. Area jernih mengindikasikan adanya hambatan pertumbuhan bakteri oleh agen antibakteri pada permukaan agar.

Tahap pertama adalah persiapan bakteri Streptococcus sanguinis. Bakteri diencerkan dengan mencampurkan 1 oese suspensi bakteri Streptococcus sangunis ke dalam tabung reaksi yang telah berisi Brain Heart Infusion Broth (BHI-B) lalu diaduk hingga kekeruhan tertentu sesuai standard McFarland ( $\left.10^{8} \mathrm{CFU} / \mathrm{mL}\right)$.

Tahap ke dua adalah pengenceran bertingkat ekstrak kulit buah delima putih untuk mendapatkan masing-masing konsentrasi $100 \%$, 
$50 \%, 25 \%, 12,5 \%$ dan 6,25\%. Tabung reaksi pertama diisi dengan ekstrak kulit buah delima putih dengan konsentrasi $100 \%$ yaitu berisi $2 \mathrm{gr} / 2 \mathrm{ml}$ ekstrak kulit buah delima putih dan aquadest steril sebanyak $2 \mathrm{ml}$. Tabung reaksi yang ke dua sampai ke lima diisi aquadest steril sebanyak $1 \mathrm{ml}$. Konsentrasi $50 \%$ pada tabung ke dua didapatkan dengan mengambil $1 \mathrm{ml}$ ekstrak kulit buah delima putih dari tabung reaksi pertama dan dicampurkan dengan aquadest steril yang terdapat pada tabung ke dua setelah itu aduk dengan vortex sampai homogen. Lakukan hal yang sama untuk tabung ke tiga sampai tabung ke lima.

Tahap ke tiga yaitu uji aktivitas antibakteri ekstrak kulit buah delima putih, bakteri yang telah tercampur dengan BHI-B diambil menggunakan lidi kapas steril, oleskan pada petri dish Agar Darah Plate (ADP). Disc berukuran $6 \mathrm{~mm}$ berjumlah 7 diletakkan dalam 1 petri dish Agar Darah Plate (ADP), tetesi disc dengan masing-masing konsentrasi ekstrak kulit buah delima putih yaitu $100 \%$, 50\%, 25\%, 12,5\%, 6,25\%, kontrol positif chlorhexidine $0,2 \%$ dan kontrol negatif yaitu aquadest steril sebanyak masing-masing $50 \mu \mathrm{l}$. Inkubasi pada suhu $37^{\circ} \mathrm{C}$ selama 24 jam.

Tahap terakhir penelitian adalah pengukuran diameter zona hambat menggunakan penggaris. Zona hambat (clear zone) yang terbentuk akan tampak sebagai area jernih atau bersih yang mengelilingi disc yang telah ditetesi ekstrak kulit buah delima putih serta kontrol positif dan kontrol negatif. Diklasifikasikan sebagai berikut menurut Greenwood (1995) ${ }^{10}$

Tabel 1. Klasifikasi respon hambatan pertumbuhan bakteri

\begin{tabular}{cc}
\hline Diameter Zona Terang & $\begin{array}{c}\text { Respon Hambatan } \\
\text { Pertumbuhan }\end{array}$ \\
\hline$>20 \mathrm{~mm}$ & Kuat \\
$16-20 \mathrm{~mm}$ & Sedang \\
$10-15 \mathrm{~mm}$ & Lemah \\
$<10 \mathrm{~mm}$ & Tidak ada \\
\hline
\end{tabular}

\section{HASIL PENELITIAN}

Hasil daya antibakteri ekstrak kulit buah delima putih terhadap bakteri Streptococcus sanguinis dapat dilihat sebagai berikut:

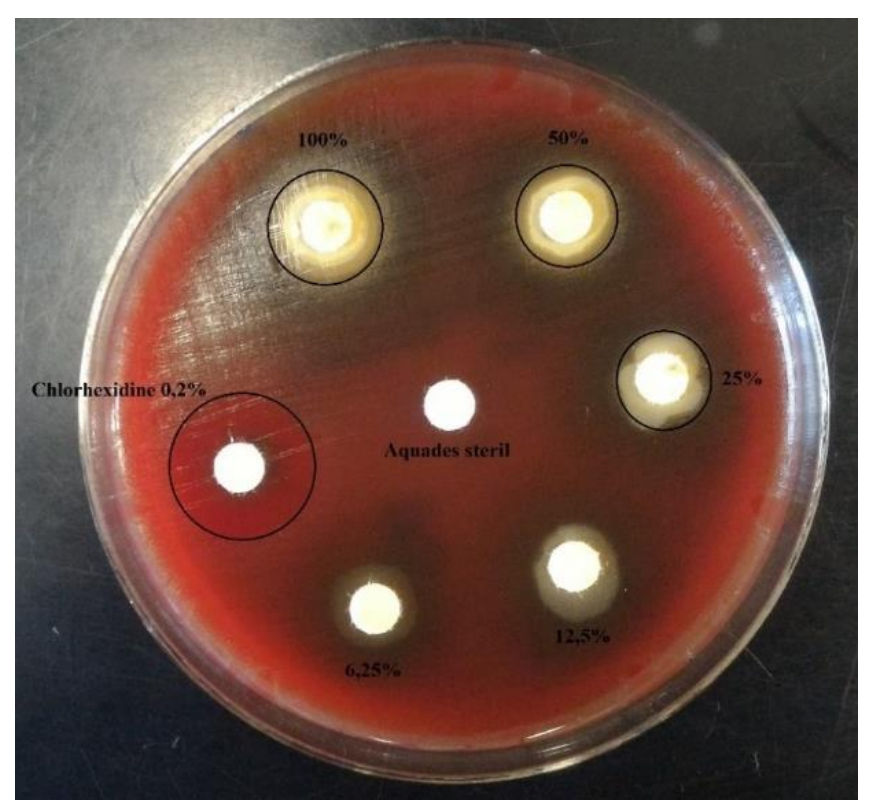

Gambar 1. Hasil zona hambat ekstrak kulit buah delima putih 
Tabel 2. Hasil zona hambat ekstrak kulit buah delima putih

\begin{tabular}{ccc}
\hline Perlakuan & $\begin{array}{c}\text { Zona hambat } \\
(\mathrm{mm})\end{array}$ & $\begin{array}{c}\text { Respon } \\
\text { hambatan }\end{array}$ \\
\hline $100 \%$ & $16,00 \mathrm{~mm}$ & Sedang \\
$50 \%$ & $14,25 \mathrm{~mm}$ & Lemah \\
$25 \%$ & $12,00 \mathrm{~mm}$ & $\begin{array}{c}\text { Lemah } \\
\text { Tidak ada }\end{array}$ \\
$6,5 \%$ & - & $\begin{array}{c}\text { Tidak ada } \\
\text { Sedang }\end{array}$ \\
$\begin{array}{c}\text { Chlorhexidine 0,2\% } \\
\text { (kontrol positif) }\end{array}$ & $18,00 \mathrm{~mm}$ & $\begin{array}{c}\text { Sidak ada } \\
\text { Aquadest steril } \\
\text { (kontrol negatif) }\end{array}$ \\
\hline
\end{tabular}

Variabel dalam penelitian ini adalah variabel kategorik-numerik tidak berpasangan dan memiliki lebih dari dua data, oleh karena itu dilakukan uji kebermaknaan dengan menggunakan One Way Annova. Sebelum melakukan uji kebermaknaan tersebut ada 2 syarat yang harus dipenuhi yaitu distribusi data normal dengan $p>0,05$ dan variansi data normal dengan $p>0,05$. Data penelitian diatas menunjukan bahwa data tidak memenuhi syarat untuk dilakukan uji One Way Annova, maka digunakan uji Kruskall-Wallis. Uji Kruskall-Wallis menunjukkan nilai signifikan atau bermakna sehingga dapat dikatakan bermakna jika $p<0,05$. Perhitungan uji Kruskall-Wallis didapatkan nilai $\mathrm{p}=$ 0,000 yang berarti lebih kecil dari $p=0,05$ yang terdapat perbedaan bermakna pada konsentrasi ekstrak kulit buah delima putih terhadap pertumbuhan bakteri Streptococcus sangunis. Uji Mann-Whitney dilanjutkan untuk melihat perbedaan yang bermakna pada tiap konsentrasi. Berikut ini merupakan uji dengan Mann-Whitney:

Tabel 2. Hasil analisis dengan menggunakan uji Mann-Whitney

\begin{tabular}{cccccccc}
\hline Konsentrasi & $6,25 \%$ & $12,5 \%$ & $25 \%$ & $50 \%$ & $100 \%$ & Chlorhexidine $0,2 \%$ & Aquadest steril \\
\hline $6,25 \%$ & - & 1,000 & ${ }^{*} 0,008$ & ${ }^{*} 0,011$ & ${ }^{*} 0,008$ & ${ }^{*} 0,008$ & 1,000 \\
$12,5 \%$ & 1,000 & - & ${ }^{*} 0,008$ & ${ }^{*} 0,011$ & ${ }^{*} 0,008$ & ${ }^{*} 0,008$ & 1,000 \\
$25 \%$ & ${ }^{*} 0,008$ & ${ }^{*} 0,008$ & - & ${ }^{*} 0,011$ & ${ }^{*} 0,008$ & ${ }^{*} 0,008$ & 1,000 \\
$50 \%$ & ${ }^{*} 0,011$ & ${ }^{*} 0,011$ & ${ }^{*} 0,011$ & - & ${ }^{*} 0,011$ & ${ }^{*} 0,011$ & 1,000 \\
$100 \%$ & ${ }^{*} 0,008$ & ${ }^{*} 0,008$ & ${ }^{*} 0,008$ & ${ }^{*} 0,011$ & - & ${ }^{*} 0,008$ & ${ }^{*} 0,008$ \\
$\begin{array}{c}\text { Chlorhexidine } \\
0,2 \%\end{array}$ & ${ }^{*} 0,008$ & ${ }^{*} 0,008$ & ${ }^{*} 0,008$ & ${ }^{*} 0,011$ & ${ }^{*} 0,008$ & - & - \\
$\begin{array}{c}\text { Aquadest } \\
\text { steril }\end{array}$ & 1,000 & 1,000 & 1,000 & 1,000 & ${ }^{*} 0,008$ & ${ }^{*} 0,008$ & \\
${ }^{*} \mathrm{P}<0,05=$ Signifikan (terdapat perbedaan bermakna) & & &
\end{tabular}

Hasil uji post hoc didapatkan perbedaan antar konsentrasi dinyatakan bermakna apabila didapatkan nilai $\mathrm{p}<0,05$. Masing-masing konsentrasi memiliki perbedaan yang bermakna kecuali pada konsentrasi $12,5 \%$ dan $6,25 \%$ yang tidak memiliki perbedaan bermakna. Terdapat perbedaan yang bermakna antar setiap konsentrasi dan dibandingkan dengan chlorhexidine $0,2 \%$ pada tingkat kepercayaan 95\%, diketahui juga bahwa respon yang terbentuk dari penghambatan tumbuhnya bakteri Streptococcus sanguinis merupakan respon lemah sampai sedang.

\section{DISKUSI}

Buah delima yang dipakai dalam penelitian ini adalah jenis buah delima yang isinya berwarna putih dikarenakan penelitian Dewi tahun 2014 menyatakan bahwa delima putih lebih banyak mengandung tanin dibandingkan delima merah. ${ }^{11}$ dan yang digunakan dalam pembuatan ekstrak dalam penelitian ini adalah kulitnya. Penelitian Hassnawi tahun 2017 menyatakan bahwa kulit buah delima banyak mengandung fenol yang terdiri dari flavonoid dan tanin, ellagic acid juga ditemukan paling banyak di kulit buah delima. ${ }^{12}$ 
Ekstrak kulit buah delima (Punica granatum $L)$ yang dipakai dalam penelitian ini diekstrak di Laboratorium Herbal Universitas Yarsi. Ekstraksi yang dilakukan menggunakan metoda maserasi dengan pelarut etanol $70 \%$. Penelitian Vongsak tahun 2017 yang meneliti ekstrak daun Morenga oleifera dengan menggunakan metoda maserasi menunjukan hasil yang tinggi dari kandungan total fenol, total flavonoid, senyawa aktif utama lainnya. ${ }^{13}$ Penelitian Panchal tahun 2013 menyatakan bahwa ekstrak kulit buah delima dengan menggunakan etanol menunjukan uji antibakteri yang lebih baik dibandingkan dengan pelarut metanol. ${ }^{14}$

Bakteri yang diujikan pada penelitian ini adalah bakteri Streptococcus sanguinis dikarenakan penelitian terhadap Streptococcus sanguinis masih terbatas, sedangkan bakteri ini banyak ditemukan pada plak gigi, yang kemudian dapat menyebabkan karies gigi. Streptococcus sanguinis berfungsi sebagai penjangkar untuk kolonisasi mikroorganisme lainnya yang akan berkolonisasi di permukaan gigi, membentuk plak gigi dan berkontribusi terhadap perkembangan karies. ${ }^{1,2}$ Streptococcus sanguinis dapat melakukan adhesi pada pelikel gigi. Bakteri ini memiliki pili, struktur sel unik filamentosa permukaan yang panjang sehingga dapat berikatan dengan reseptor yang ada pada pelikel seperti asam sialik dan $\alpha$ amilase. ${ }^{15}$

Metoda yang dilakukan untuk menguji daya antibakteri pada penelitian ini adalah metoda disc diffusion yaitu menggunakan disc yang ditanam pada media Agar Darah Plate (ADP), menurut penelitian Krihariyani tahun 2016, media agar darah mengandung darah mamalia (umumnya domba) yang tidak beku sebanyak 5-10\%. Penambahan darah tersebut bertujuan untuk mempersubur perbenihan dan untuk menumbuhkan bakteri yang sukar tumbuh pada perbenihan biasa. ${ }^{16}$ Didapatkan zona hambat dengan cara melihat zona bening atau jernih yang terbentuk pada sekitar disc yang dilakukan di Lab Mikrobiologi Universitas Yarsi. Ekstrak kulit buah delima putih yang dibuat dalam berbagai konsentrasi adalah untuk melihat perbedaan signifikan masing-masing konsentrasi ekstrak kulit buah delima putih (Punica granatum $L$ ) sebagai antibakteri terhadap bakteri Streptococcus sanguinis.

Berdasarkan penelitian yang telah dilakukan di Lab Herbal dan Mikrobiologi Universitas Yarsi, ekstrak kulit buah delima putih mampu menghambat pertumbuhan Streptococcus sanguinis. Konsentrasi 6,25\% maupun 12,5\% terlihat tetesan yang meluber dari disc, namun tidak ditemukan adanya zona hambat, hal ini dikarenakan media agar yang digunakan masih baru dan masih memiliki kandungan air yang tinggi sehingga ekstrak yang diteteskan kurang meresap ke dalam agar. Konsentrasi 25\% didapatkan respon hambat adalah lemah. Konsentrasi $50 \%$ juga didapatkan respon hambat lemah, sementara pada konsentrasi $100 \%$ didapatkan respon hambat sedang. Hasil ini sejalan dengan penelitian Susetyo tahun 2017 yang menguji ekstrak buah delima merah terhadap bakteri Porphyromonas gingivalis. ${ }^{17}$ Hasil penelitian uji daya hambat pada media Agar Darah Plate (ADP) menunjukan bahwa semakin tinggi konsentrasi ekstrak kulit buah delima putih semakin besar zona hambat yang terbentuk di sekitar disc.

Chlorhexidine 0,2\% digunakan sebagai kontrol positif memiliki respon hambatan sedang, chlorhexidine sangat luas digunakan yang memiliki sifat antimikroba terhadap bakteri gram positif, bakteri negatif spora bakteri, virus lipofilik, dan jamur. Chlorhexidine merupakan obat kumur yang efektif sebagai agen kontrol terhadap plak. ${ }^{18}$ Kontrol negatif yang digunakan adalah aquadest steril, hal ini adalah untuk memastikan bahwa efek 
antibakteri terhadap kuman Streptococcus sanguinis berasal sepenuhnya dari ekstrak kulit buah delima putih (Punica granatum L) dan tidak ada dari aquadest steril. Hasil yang didapatkan bahwa tidak ditemukan adanya respon hambatan aquadest steril terhadap Streptococcus sanguinis.

Beberapa faktor yang mempengaruhi adanya zona hambat bergantung kepada kemampuan difusi bahan antibakteri ke dalam media dan interaksinya dengan bakteri yang diuji, kecepatan tumbuh bakteri yang diuji, dan sensitivitas bakteri terhadap bahan antibakteri yang diuji. Bahan pelarut yang digunakan juga memiliki pengaruh terhadap terbentuknya zona hambat di sekitar disc. Zat ekstrak yang tergantung pada tumbuhan itu sendiri juga memiliki pengaruh pada daya hambat kulit buah delima putih terhadap bakteri Streptococcus sanguinis. ${ }^{10}$

Efek antibakteri ekstrak kulit buah delima putih terhadap pertumbuhan bakteri Streptococcus sanguinis diduga karena kandungan fenol dan derivatnya seperti flavonoid dan tanin. Fenol memicu inaktivasi enzim seluler sehingga terjadi perubahan permeabilitas membran. Melalui proses koagulasi, fenol bisa merusak organ intraseluler bakteri. ${ }^{19}$ Penelitian Putri 2014 menyatakan bahwa kandungan fenol yang terdapat pada buah rosela merah dan ungu memiliki sifat antibakteri terhadap Staphylococcus aureus dan Eschericia coli. ${ }^{20}$

Flavonoid merupakan kelompok senyawa fenol yang mempunyai kecenderungan menghambat sintesis dari asam nukleat bakteri, menghambat fungsi membran sitoplasmik bakteri, dan menghambat metabolisme energi bakteri. ${ }^{21}$ Menurut penelitian Parubak tahun 2013 yang menyatakan bahwa flavonoid memiliki sifat antibakteri yang terdapat pada daun akway terbukti mempunyai daya hambatan terhadap bakteri gram positif dan gram negatif. ${ }^{22}$ Penelitian Sari tahun 2015 juga menyatakan bahwa tanin memiliki sifat antibakteri dari daun trembesi terhadap bakteri Escherichia coli. ${ }^{23}$ Tanin menghambat dekomposisi bahan organik padat melalui penghambatan enzim dari mikroorganisme yang menyerang. Efek tanin sebagai antibakteri nampak dari kemampuan melewati dinding sel bakteri yang terdiri dari polisakarida dan protein dan berikatan dengan permukaanya. ${ }^{21}$

\section{KESIMPULAN}

Ekstrak kulit buah delima putih memiliki daya antibakteri terhadap bakteri Streptococcus sanguinis di antara konsentrasi 25\%,50\% dan $100 \%$. Terdapat perbedaan signifikan masingmasing konsentrasi ekstrak kulit buah delima putih terhadap bakteri Streptococcus sanguinis kecuali pada konsentrasi $6,25 \%$ dengan $12,5 \%$. Semakin tinggi konsentrasi ekstrak kulit buah delima putih semakin besar zona hambat yang terbentuk di sekitar disc.

\section{DAFTAR PUSTAKA}

1. Putri, MH. Ilmu pencegahan penyakit jaringan keras dan jaringan pendukung gigi. Jakarta: EGC; 2011.pp.234.

2. Attamimi, FA. Antibacterial activity test of ant nest tuber (Myrmecodia Pendens) crude extract against Streptococcus sanguinis compared to chlorhexidine. MKB 2015;49(2):94-101.

3. Dutt P, Rathore PK, Khurana D. Chlorhexidine - an antiseptic in periodontics. IOSR-JDMS 2014;13(9):85-8.

4. Adji S. Terbukti pome tumpas penyakit. Pustaka Bunda; 2011.p.71.

5. Khasanah, N. Kandungan buah-buahan dalam Al-Qur'an, buah tin, zaitun, delima, anggur, dan kurma untuk kesehatan. J Phenom 2011;1(1):5-29.

6. Utomo, H. Oetomo, KC. Pomegranate juice (Punica granatum) as an ideal mouthrinse for 
fixed orthodontic patients. Dent J (Majalah Kedokteran Gigi) 2012;45(4):221.

7. Sukmawati, VO. Daya antibakteri dekokta kulit buah delima putih (Granati fructus cortex) terhadap Streptococcus mutans (Antibacterial of decocta granati fructus cortex to Streptococcus mutans). Artikel IImiah Hasil Penelitian Mahasiswa 2013:4.

8. Sabrina, GA. Daya antibakteri fraksi n-butanol kulit buah delima putih (Granati fructus cortex) terhadap Streptococcus mutans. 2015;3(3):541.

9. Sadeghian A, Ghorbani A, Mohamadi-nejad A, Rakhshandeh H. Antimicrobial activity of aqueous and methanolic extracts of pomegranate fruit skin. Avicenna Journal of Phytomedicine 2011;1(2):67-73.

10. Alfath Cut R. Antibacterial effect of granati fructus cortex extract on Streptococcus mutans in vitro. J Dent Indonesia 2013;20(1):5-8.

11. Dewi, MA. Determination of total tannin of white and red rind pomegranate (Punica granatum $L$ ) by colorimetry method using reagent. Procedia Chemistry 2014;13:214-7.

12. Al Hassnawi, AA. Evaluation of antibacterial activity of aqueous and methanolic extracts of pomegranate peels (Punica Granatum Lin.) against some bacteria. World Journal of Pharmaceutical Research 2017;6(8):2426-36.

13. Vongsak B, Sithisarn $P$, Mangmool $S$, Thongpraditchote S, Wongkrajang $\mathrm{Y}$, Gritsanapan W. Maximizing total phenolics, total flavonoids contents and antioxidant activity of Moringa oleifera leaf extract by the appropriate. Elsevier 2017;44:566-71.

14. Swadaya T. Herbal dari kitab suci. Jakarta: Redaksi Trubus; 2013.pp.136

15. Okahashi N. Streptococcus sanguinis binds to salivary amylase and promote the biofilm formation. Elsevier 2011;50(3):148-54.

16. Dwi K. Pertumbuhan Staphylococcus aureus pada media agar darah manusia golongan $O$, $A B$, dan darah domba sebagai kontrol. J IImu dan Teknol Kesehat. 2013;3(2):191-200.

17. Susetyo AA. Daya hambat ekstrak buah delima merah (Punica granatum Linn) terhadap pertumbuhan Porphyromonas gingivalis. Jurnal Pustaka Kesehat 2017;5(2):352-5.

18. Rosidah AN. Daya antibakteri ekstrak daun kendali (Hippobroma longiflora) terhadap pertumbuhan Streptococcus mutans. Jurnal Pustaka Kesehatan 2014:6.

19. Karaca HC. Evaluation of natul antimicrobial phenolic compounds against foodborne pathogens (tesis). Kentucky: University of Kentucky; 2011.pp.196.

20. Putri DD. Kandungan total fenol dan aktivitas antibakteri kelopak buah rosela merah dan ungu sebagai kandidat feed additive alami pada broiler. Jurnal Penelitian Pertanian Terapan. 2014;14(3):174-80.

21. Duman AD. Antimicrobial activity of six pomegranate (Punica granatum L.) varieties and their relation to some of their pomological and phytonutrient characteristics. Molecules. 2009;14(5):1808-17.

22. Parubak SA. Senyawa flavonoid yang bersifat antibakteri dari akway (Drimys becariana. Gibbs). Chem Prog 2013;6(1):34-7.

23. Puspita Sari P. Identifikasi dan uji aktivitas senyawa tanin dari ekstrak daun trembesi (Samanea saman (Jacq.). sebagai antibakteri escherichia coli (E. coli). J Kim. 2015;9(1):2734. 